\title{
Acute malnutrition is associated with the high nutritional risk obtained by STRONGkids in children and adolescents with infectious diseases
}

\author{
A desnutrição aguda está associadla ao alto risco nutricional obtidlo pelo STRONGkids em crianças \\ e adolescentes com doenças infecciosas \\ La desnutrición aguda se asocia con el alto riesgo nutricional obtenido por STRONGkids en niños y \\ adolescentes con enfermedades infecciosas aligned
}

Received: 08/25/2021 | Reviewed: 08/30/2021 | Accept: 09/02/2021 | Published: 09/05/2021

\author{
Francisca Maria da Silva \\ ORCID: https://orcid.org/0000-0003-2178-4468 \\ State University of Ceara, Brasil \\ E-mail: franmaryss@hotmail.com \\ Francisca Isabelle da Silva e Sousa \\ ORCID: https://orcid.org/0000-0001-6226-3381 \\ State University of Ceara, Brasil \\ E-mail: isabelle_sousa@outlook.com \\ Alexandre Danton Viana Pinheiro \\ ORCID: https://orcid.org/0000-0001-9180-5514 \\ State University of Ceara, Brasil \\ E-mail: alexandredanton@hotmail.com \\ Ribanna Aparecida Marques Braga \\ ORCID: https://orcid.org/0000-0003-2122-5658 \\ State University of Ceara, Brasil \\ E-mail: ribanna.marques@aluno.uece.br \\ Maria Luisa Pereira de Melo \\ ORCID: https://orcid.org/0000-0002-3606-2217 \\ State University of Ceara, Brasil \\ E-mail: luisa.melo@uece.br \\ Kaluce Gonçalves de Sousa Almondes \\ ORCID: https://orcid.org/0000-0003-2694-1629 \\ State University of Ceara, Brasil \\ E-mail: kaluce.almondes@uece.br \\ Carla Soraya Costa Maia \\ ORCID: https://orcid.org/0000-0003-1535-6686 \\ State University of Ceara, Brasil \\ E-mail: carla.maia@uece.br
}

\begin{abstract}
Objective: In this study, we aim to evaluate whether the presence of malnutrition in children and adolescents with infectious diseases is associated with high nutritional risk obtained by the STRONGkids instrument. Methods: A cross-sectional study comprising 237 hospitalized patients aged between 30 days and 18 years. Identification and diagnosis data, weight and height were collected. STRONGkids determined nutritional risk. Acute malnutrition was classified by BMI/age $\mathrm{Z}$ score $<-2$ and chronic by Height/age $\mathrm{Z}$ score $<-2$. Associations between categorical variables were verified using Pearson's chi-square test. A logistic regression analysis was performed to assess the association between anthropometric parameters of malnutrition and nutritional risk. It was considered significant $\mathrm{p}<$ 0,05. Results: In multiple analysis, it was observed that having malnutrition as of BMI/age increases the chance by 5.68 of having high nutritional risk by the STRONGKids instrument, regardless of age, sex and the presence of poverty-related infectious diseases (OR: 5.68; 95\% CI: 1.54-20.93; $\mathrm{p}=0.009$ ). Conclusion: In summary, for patients with infectious diseases, acute malnutrition (BMI/age) is associated directly with the diagnosis of high nutritional risk by STRONGkids.
\end{abstract}

Keywords: Malnutrition; Hospitalized children; Infectious diseases; Nutrition assessment.

\section{Resumo}

Objetivo: Neste estudo, objetivamos avaliar se a presença de desnutrição em crianças e adolescentes com doenças infecciosas está associada ao alto risco nutricional obtido pelo instrumento STRONGkids. Métodos: Estudo transversal envolvendo 237 pacientes hospitalizados com idade entre 30 dias e 18 anos. Foram coletados dados de identificação, diagnóstico, peso e altura. O STRONGkids determinou o risco nutricional. A desnutrição aguda foi 
classificada pelo IMC/idade escore $\mathrm{Z}<-2$ e crônica pelo escore $\mathrm{Z}$ da Altura/ idade $<$ - 2. As associações entre as variáveis categóricas foram verificadas pelo teste do qui-quadrado de Pearson. Foi realizada análise de regressão logística para avaliar a associação entre parâmetros antropométricos de desnutrição e risco nutricional. Foi considerado significativo $\mathrm{p}<0,05$. Resultados: Em análise múltipla, observou-se que ter desnutrição a partir do IMC/idade aumenta em 5.68 a chance de alto risco nutricional pelo instrumento STRONGKids, independentemente da idade, sexo e presença de doenças infecciosas relacionadas à pobreza (OR: 5.68; 95\% CI: 1.54-20.93; p=0.009). Conclusão: Em resumo, para pacientes com doenças infecciosas, a desnutrição aguda (IMC/idade) está associada diretamente ao diagnóstico de alto risco nutricional pelo STRONGkids.

Palavras-chave: Desnutrição; Criança hospitalizada; Doenças infecciosas; Avaliação nutricional.

\section{Resumen}

Objetivo: En este estudio, nuestro objetivo fue evaluar si la presencia de desnutrición en niños y adolescentes con enfermedades infecciosas se asocia con el alto riesgo nutricional obtenido por el instrumento STRONGkids. Métodos: Estudio transversal en el que participaron 237 pacientes hospitalizados con edades comprendidas entre los 30 días y los 18 años. Se recogieron datos de identificación, diagnóstico, peso y talla. STRONGkids determinó el riesgo nutricional. La desnutrición aguda se clasificó por puntuación $\mathrm{Z}$ de IMC/edad < - 2 y crónica por puntuación $\mathrm{Z}$ de Talla/edad < - 2. Las asociaciones entre las variables categóricas se verificaron mediante la prueba de chi-cuadrado de Pearson. Se realizó un análisis de regresión logística para evaluar la asociación entre los parámetros antropométricos de desnutrición y el riesgo nutricional. Se consideró significativo p <0,05. Resultados: En análisis múltiple se observó que tener desnutrición con base en el IMC/edad aumenta en 5.68 la probabilidad de alto riesgo nutricional según el instrumento STRONGKids, independientemente de la edad, sexo y presencia de enfermedades infecciosas relacionadas con la pobreza (OR: 5.68; 95\% CI: 1.54-20.93; p=0.009). Conclusión: En resumen, para los pacientes con enfermedades infecciosas, la desnutrición aguda (IMC/edad) se asocia directamente con el diagnóstico de alto riesgo nutricional por parte de STRONGkids.

Palabras clave: Desnutrición; Niño hospitalizado; Enfermedades transmisibles; Evaluación nutricional.

\section{Introduction}

Child malnutrition, especially severe acute malnutrition, is a contributing factor to mortality in children under five years since malnutrition is associated with an increased risk of common childhood diseases such as pneumonia, diarrhea, and malaria (World Health Organization, 2019). Infectious diseases common in childhood are more frequent in malnourished children, highlighting the synergistic relationship between these factors (Pooja et al., 2019), which impact the high prevalence of malnutrition and the high mortality rates in pediatric patients with infectious diseases, such as HIV and tuberculosis Hussien et al (2019); Nalwang et al (2020).

In Brazil, there was a reduction in the proportion of deaths associated with infectious diseases, this trend is related to the reduction of deaths from diarrhea and the increase in vaccination coverage Waldman and Sato (2016). However, it is noteworthy that despite the reduction in morbidity and mortality by infectious and parasitic diseases, these persist in the Brazilian scenario De Souza et al (2020). They are associated with worse living conditions of the population, as is this case of infectious diseases of poverty (IDoP), which comprise the neglected tropical diseases Harris et al (2012).

Malnutrition in hospitalized children is associated with unfavorable clinical outcomes and more extended hospital stays and greater disease severity Niseteo et al (2020). Therefore, it is essential to assess nutritional status and nutritional risk at hospital admission, so that dietary interventions can be performed early on patients at risk of malnutrition Moreno et al (2019); Beser et al (2018).

The nutritional risk, nutritional screening tools have been developed in pediatrics. One of these Tools, the Screening for Risk in Nutritional Status and Growth (STRONGkids), has been validated for the Brazilian population Texeira \& Viana (2016). STRONGkids performs well in assessing nutritional status upon hospital admission Gouveia et al (2018), has good accuracy, high sensitivity in early detection of nutritional risk Maciel et al (2020), and appears to be directly associated with length of hospital stay Gouveia et al (2018).

The importance of screening for nutritional risk in pediatric patients with acute conditions is highlighted. The consequences of infectious diseases on nutritional status can compromise the child's development and growth. It is crucial to 
choose a useful instrument for assessing nutritional risk in these patients to perform adequate nutritional interventions early. Besides, the scientific literature lacks studies that evaluate the topic of the use of the STRONGkids instrument in the assessment of nutritional risk in pediatric patients with infectious diseases. Therefore, this study aimed to evaluate whether the presence of malnutrition in children and adolescents with infectious diseases is associated with high nutritional risk obtained by the STRONGkids instrument.

\section{Methodology}

This is an analytical cross-sectional study carried out in a Public Referal Hospital for the treatment of infectious diseases in the State of Ceara, from August 2016 to July 2017. The sample was obtained for convenience and consisted of 237 pediatric patients treated for infectious diseases, aged over 30 days and under 18 years of age, who were able to perform the procedures. The study was approved by the Research Ethics Committee of Hospital São José - Ceara/Brazil (CAAE: 64268217.0000.5044) Pereira et al (2018).

Data were collected using a structured questionnaire to characterize the sample, such as age, sex, and reason for hospitalization. The children were classified into two groups according to the presence or absence of IDoP. The following infectious diseases and parasitic diseases were considered IDoP: Viral (Dengue and Rabies), Protozoan (Human African trypanosomiasis, Chagas disease, Leishmaniasis), Helminth (Cysticercosis/Taeniases, Dracunculiasis, Echinococcosis, Food borne trematodiasis, Lymphatic filariasis, Onchocerciasis, Schistosomiasis, Ascariasis, Trichuriasis, Hookworm disease, Bacterial (Buruli ulcer, Leprosy, Trachoma, Yaws), Tuberculosis, HIV/AIDS, Malaria Harris et al (2012).

To assess nutritional status, weight, and height were collected, following the guidelines of the Ministry of Health, Brasil (2011). To identify nutritional risk, the adapted and translated STRONGkids tool was applied (Carvalho et al., 2013). The arm circumference was performed preferably in the right arm, with the aid of a millimeter inelastic tape measure, according to the guidelines of the Ministry of Health, Brasil (2011).

To measure the weight of children younger than 24 months, an electronic pediatric scale was used, and for children older than 24 months, a platform-type scale (Balmak®, Brazil) was used, both instruments were calibrated. The height (length/height) of children under 24 months was measured using a children's stadiometer, which was placed on a smooth and stable surface, in which the child was positioned in the supine position, in the center of the equipment, with a straight neck, chin away from the chest. With the parents' help, the knees were pressed, and the hands were placed on the sides of the body. For older than 24 months, height was measured with the child standing, using a stadiometer attached to a scale (Balmak®, Brazil).

Anthropometric indices were estimated for height for age (H/A), weight for age (W/A), body mass index for age (BMI/age), weight for height (W/H), the last parameter is calculated only for children under five years Brasil (2011). The cutoff point for the diagnosis of malnutrition was Z-score <- 2. For chronic malnutrition, the anthropometric H/A index was used, and for acute malnutrition, the BMI/age index results were considered (World Health Organization, 2006). Anthropometric data were entered into the WHO Anthro (version 3.2.2, 2011) and WHO Anthro Plus (version 3.2.2, 2009) software to determine the $\mathrm{Z}$-scores for the $\mathrm{H} / \mathrm{A}$ and $\mathrm{BMI} / \mathrm{age}$ ratios.

The assessment of nutritional risk was carried out in the first 48 hours of hospitalization, using the STRONGkids tool. It was based on four questions scored on diagnosis, subjective assessment, weight change, and food intake. In the end, the sum of these points was carried out, and the nutritional risk was identified: low risk ( 0 points), medium risk ( 1 to 3 points), and high risk (4 to 5 points). The researcher evaluated the first two items, and the next two were evaluated/discussed with the parents and/or caregivers of the children and adolescents included in the investigation.

Initially, descriptive analyses were performed, with categorical variables expressed as simple frequencies and 
percentages and numerical variables as measures of central tendency (means or medians) and dispersion (standard deviation or interquartile range). Data normality and homogeneity were verified using the Shapiro-Wilk and Levene tests, respectively. Associations between categorical variables were verified using Pearson's chi-square test. For comparisons of means between two categories (nutritional risk), depending on normality and homogeneity, the Student's t-test for independent samples was used when data were parametric or the Mann-Whitney test when data were non-parametric.

A logistic regression analysis was performed to assess the association between anthropometric parameters of malnutrition and nutritional risk. The nutritional risk obtained by STRONGKids (medium/high risk) was considered as dependent variable. The variables BMI/age (with/without malnutrition), height/age (with/without malnutrition) and arm circumference (numeric) were considered as independent variables; age (numeric), sex (male/female) and poverty-related infectious diseases (yes/no) were considered as confounding variables.In the multiple analysis, three models were used: model 1 without adjustment, model 2 adjusted for sex and age, and model 3 adjusted for sex, age, and poverty infectious diseases. The study variables were compared using the Wald test.

The selection method for the variables was the forward and, it was adopted as a criterion for the selection of the variables in the modeling the value of $\mathrm{p} \leq 0.20$ of the likelihood ratio test of the univariate regressions. To keep the variables in the model, the criteria adopted were: $p \leq 0.05$ of the Wald test or a reduction of at least $10 \%$ in the value of the estimated $\beta$ of at least one of the other significant variables when compared to the previous model. The constructed models were fitted using the Hosmer-Lemeshow goodness of fit test. The analyses were performed using the statistical software Statistical Package for the Social Sciences (SPSS) version 22.0, adopting a significance level of $5 \%(\mathrm{p}<0.05)$.

\section{Results}

The study included 237 individuals with a mean age of 95.91 ( $\mathrm{SD}=69.88)$ months, ranging from 1 to 215 months, and $38.8 \%$ were under 5 years of age. More than half were (50.6\%) male and $36.3 \%$ had poverty-related infectious diseases, with significantly higher prevalence in the high nutritional risk group. Regarding nutritional status, it was observed that most individuals were eutrophic (70.5\%) and, in addition, acute malnutrition obtained by BMI/age was more prevalent in the group with high nutritional risk $(81.8 \%)$, while overweight had a higher percentage in the medium nutritional risk, 64.2\% ( $<<0.001)$. The BMI means showed statistically significant differences between the nutritional risk groups, being lower in the high risk compared to the medium nutritional risk $(\mathrm{p}=0.003)$. The other variables showed no significant differences between the nutritional risk groups ( $\mathrm{p}>0.05)$ (Table 1$)$. 
Table 1. Sociodemographic factors and anthropometric characteristics of children and adolescents according to the categories of nutritional risk of the STRONGkids instrument (n=237). Fortaleza, Ceara, 2016 - 2017.

\begin{tabular}{|c|c|c|c|c|}
\hline \multirow{3}{*}{ Variable } & \multicolumn{4}{|c|}{ Nutritional Risk } \\
\hline & Total & Medium & High & \\
\hline & $\mathrm{n}(\%)$ & $\mathrm{n}=137(57.8 \%)$ & $\mathrm{n}=100(42.2 \%)$ & $\mathrm{p}$ \\
\hline \multicolumn{5}{|l|}{ Sociodemographic factors } \\
\hline \multicolumn{5}{|l|}{ Sex } \\
\hline Male & $120(50.6)$ & $64(53.3)$ & $56(46.7)$ & \multirow{2}{*}{0.158} \\
\hline Female & $117(49.4)$ & $73(63.4)$ & $44(37.6)$ & \\
\hline \multicolumn{5}{|l|}{ Age range } \\
\hline$<5$ years & $92(38.8)$ & $57(62.0)$ & $35(38.0)$ & \multirow{3}{*}{0.538} \\
\hline 5 to $<10$ years & $63(26.6)$ & $36(57.1)$ & $27(42.9)$ & \\
\hline 10 to 19 years & $82(34.6)$ & $44(53.7)$ & $38(46.3)$ & \\
\hline $\mathrm{Age}_{(\text {months) }}$, mean $(\mathrm{SD})$ & $95.91(69.88)$ & $91.15(70.72)$ & $102.43(68.52)$ & $0.218^{*}$ \\
\hline \multicolumn{5}{|l|}{ Infectious Diseases of Poverty } \\
\hline No & $151(63.7)$ & $99(65.6)$ & $52(34.4)$ & \multirow{2}{*}{0.001} \\
\hline Yes & $86(36.3)$ & $38(44.2)$ & $48(55.8)$ & \\
\hline \multicolumn{5}{|l|}{ Nutritional status } \\
\hline \multicolumn{5}{|l|}{ BMI/Age } \\
\hline Thinness & $17(7.2)$ & $3(17.6)$ & $14(82.4)$ & \multirow{3}{*}{$<0.001$} \\
\hline Eutrophic & $167(70.5)$ & $100(59.9)$ & $67(40.1)$ & \\
\hline Excess weight & $53(22.4)$ & $34(64.2)$ & $19(35.8)$ & \\
\hline BMI/age $_{(\mathrm{z} \text { score })}$, median (IQR) & $0.02(-1.05 ; 0.87)$ & $0.32(-0.42 ; 1.01)$ & $-0.76(-1.72 ; 0.81)$ & $<0.001^{£}$ \\
\hline $\mathrm{BMI}_{\left(\mathrm{kg} / \mathrm{m}^{2}\right)}$, mean $(\mathrm{SD})$ & $17.58(3.95)$ & $18.23(3.80)$ & $16.69(4.00)$ & $\mathbf{0 . 0 0 3}$ \\
\hline \multicolumn{5}{|l|}{ Height/age } \\
\hline Short stature & $223(94.1)$ & $127(57.0)$ & $96(43.0)$ & \multirow{2}{*}{0.287} \\
\hline Adequate stature & $14(5.9)$ & $10(71.4)$ & $4(28.6)$ & \\
\hline Height/age $_{(\mathrm{z} \text { score })}$, mean $(\mathrm{SD})$ & $0.31(2.84)$ & $0.48(3.50)$ & $0.07(1.50)$ & 0.219 \\
\hline $\mathrm{BC}_{(\mathrm{cm})}$, mean $(\mathrm{SD})$ & $19.17(5.00)$ & $19.42(5.27)$ & $18.83(4.61)$ & $0.360^{*}$ \\
\hline
\end{tabular}

n: frequency; SD: standard deviation; IQR: interquartile range; BMI: body mass index; BC: brachial circumference; $p$ value $<0.05$. Pearson's chi-square; ${ }^{£}$ Mann-Whitney test; ${ }^{\ddagger}$ Studant's t-test. Source: Authors

In multiple analysis, it was observed that having malnutrition as of BMI/age increases the chance by 5.68 of having high nutritional risk by the STRONGKids instrument, regardless of age, sex and the presence of poverty-related infectious diseases (OR: 5.68; 95\% CI: 1.54-20.93; p=0.009). In addition, increasing the arm circumference by one centimeter reduces the chance of having a high nutritional risk by 10\%, independent of age, sex, and the presence of poverty-related infectious diseases (OR: 0.90; 95\%CI: 0.82-0.98; $\mathrm{p}=0.022)$. The height/age index was not associated with nutritional risk ( $\mathrm{p}>0.05)($ Table 2). 
Table 2. Association between acute (BMI/age), chronic (Stature/age) malnutrition, brachial circumference and high nutritional risk obtained by the STRONGKids instrument. Fortaleza, Ceara, 2016 - 2017.

\begin{tabular}{|c|c|c|c|c|c|c|}
\hline \multirow{3}{*}{ Malnutrition } & \multicolumn{6}{|c|}{ High Nutritional Risk } \\
\hline & \multirow{2}{*}{$\begin{array}{c}\text { Model } 1 \\
\text { OR (CI 95\%) }\end{array}$} & \multicolumn{3}{|c|}{ Model 2} & \multicolumn{2}{|l|}{ Model 3} \\
\hline & & $\mathrm{p}$ & OR (CI 95\%) & $\mathrm{p}$ & OR (CI 95\%) & $\mathrm{p}$ \\
\hline \multicolumn{7}{|l|}{ BMI/age } \\
\hline without & Ref. & & Ref. & & Ref. & \\
\hline with & $7.27(2.03-26.04)$ & 0.002 & $6.61(1.82-23.98)$ & 0.004 & $5.68(1.54-20.93)$ & 0.009 \\
\hline \multicolumn{7}{|l|}{ Height/age } \\
\hline without & Ref. & & Ref. & & Ref. & \\
\hline with & $0.52(0.16-1.73)$ & 0.294 & $0.53(0.16-0.79)$ & 0.311 & $0.40(0.11-1.39)$ & 0.411 \\
\hline Arm circumference $(\mathrm{cm})$ & $0.97(0.92-1.02)$ & 0.369 & $0.88(0.81-0.96)$ & 0.007 & $0.90(0.82-0.98)$ & 0.022 \\
\hline
\end{tabular}

Ref: reference; BMI: body mass index; BC: arm circumference; OR: odds ratio; CI 95\%: 95\% confidence interval; $\mathrm{p}$ value $<0.05$. Simple and multiple binary logistic regression: model 1: no adjustment; model 2: adjusted for age and sex; model 3: adjusted for age, sex, and infectious diseases. Source: Authors.

\section{Discussion}

Our investigation demonstrates the high impact that infectious diseases have on nutritional risk and nutritional status, not depending on the specific disease analyzed. Among our results, we saw that the type of IDoP was not able to interfere in the relationship between the presence of malnutrition and nutritional risk. Gashaw, Bekele, Mekonnen, Medhin, Ameni and Erko (2019) observe either BMI values were not associated with individuals with co-infections resulting from tuberculosis, when compared to the group of individuals with only tuberculosis.

A possible justification for this finding can be represented by the various types of infectious diseases that can equally affect the nutritional status, where they would also generate a risk for malnutrition, thus, all producing an additional point in the STRONGkids. In addition, the prognosis of the nutritional status of children over time during hospitalization may depend more on the specific disease, and it should be taken into account that the current research was carried out in a cross-sectional analysis in the initial moments of hospitalization.

We decided to make a division between acute and chronic malnutrition, as well as other authors Bélanger et al (2019); Márquez Costa, Alberici Pastore (2015), to better predict the type of malnutrition that occurs in the individual, where acute malnutrition is understood as hospitalization or underlying disease being the causative factor, and chronic as some nutritionrelated disorder that started before admission (World Health Organization, 2006). Especially in western countries, children are commonly hospitalized due to acute health events Beser, Cokugras, Erkan, Kutlu, Yagci (2018).

The present study showed a high prevalence of poverty-related infectious diseases in individuals with high nutritional risk. Furthermore, a direct association was observed between acute malnutrition, evidenced by BMI/age, and high nutritional risk, while increased arm circumference was protective of high nutritional risk obtained by the STRONGkids instrument. It is noteworthy that the type of IDoP did not interfere in the relationship between the presence of malnutrition and the nutritional risk obtained by the STRONGkids instrument.

In the pediatric population, recommendations for nutritional screening are scarce Teixeira, Viana (2016); Gouveia, Tassitano, Silva (2018). In Brazil, only two tools are validated for use in pediatrics, STRONGkids Carvalho, Lopes, Vilela, Vieira, Rinaldi, Crispim (2013), and the Subjective Global Nutritional Assessment (ANSG) World Health Organization (2006). However, the research on the clinical application of these instruments is limited. According to our knowledge, this is the first study in which a nutritional risk tool validated in Brazil is applied only to patients with infectious diseases. 
The rapid identification of children with nutritional risk in a hospital environment, through the application of risk screening techniques, confers higher power of intervention in those patients whose assessment and nutritional adjustment would occur in an agile and early manner. This fact is justified by the time necessary to carry out a detailed nutritional evaluation in all patients, with such procedures being prolonged and often unfeasible in conditions that require early nutritional intervention. Besides, nutritional screening makes it possible to reduce hospital expenses and occupy beds, since STRONGkids provides a relationship between the classification of nutritional risk and the length of hospital stay Bélanger et al. (2018).

The high prevalence of diseases of poverty in children at nutritional risk was observed in the current study, as well as also observed by Feleke, Feleke, Biadglegne (2019), where 57\% of the individuals analyzed with tuberculosis were underweight, in addition to $88 \%$ being anemic. For children, the result observed by Erismann et al. (2017) was similar, where malnutrition, stunting and thinness were associated with parasitic infections, emphasizing the importance of prior identification of the risk of malnutrition in hospitalized children through the application of appropriate questionnaires.

According to the guides of the European Society of Parenteral and Enteral Nutrition (ESPEN), a nutritional risk screening has the main objective of detecting protein-energy malnutrition or pre-development and worsening Hecht et al. (2015); Costa and Pastore (2015); Rinninella et al. (2017). Nutritional risk assesses factors related to the patient's previous nutritional status, as well as considering other aspects, such as weight loss, food inappetence, presence of conditions that may interfere with food intake and nutrient absorption, as well as diseases and comorbidities presented by patients Beser et al. (2018). Thus, other authors found different results from the current study, being evaluated using anthropometric parameters and identifying nutritional risk in children without malnutrition Brazil (2011); Márquez Costa, Alberici Pastore (2015). In the present study, where children had lower BMI averages at the same time that they had high nutritional risk, compared to those with medium nutritional risk.

The release of inflammatory mediators, combined with the pro-oxidative state caused by infectious diseases, can seriously compromise the nutritional status of these pediatric patients. During cachexia, or malnutrition, present in a hospital environment, the increase in pro-inflammatory cytokines, such as IL- 6 and TNF- $\alpha$, can interfere with the distribution of fat and muscle tissue, especially in the arm, evidenced by the circumference of the arm, reducing -as, in addition to increasing the Basal Energy expenditure (BEE) and alter the regulatory axis of hunger / satiety, to reduce appetite, consequently causing an acute reduction in food intake Bhutta, Berkley, Bandsma, Kerac, Trehan, Briend (2017).

In our study, we found that, once a child is malnourished by BMI/age, there is an increase of 5.68 times the chance of also being accompanied by nutritional risk, reflecting the tool's good performance in detecting the risk. Similar to these findings, Arzoz-Gambra et al. (2019) also identified significantly lower BMI/age scores in children with high nutritional risk hospitalized due to infectious diseases, in comparison with those of low and medium risk.

The application of nutritional screening tools, in order to identify nutritional risk, is not always applied at the same time that another method of body measurements is performed, such as weight, height, arm circumference or skin folds, especially in children Hauysentruyt et al. (2015). Sisay, Haile, Hassen, Gebreyesus (2021) identified, in their study, that the average arm circumference obtained a good level of precision to identify thinness in adolescents, suggesting use for screening nutritional risk. In our study, following the same reasoning, the mean circumference of the larger arm is related to a reduced risk presented by the screening tool, suggesting that the increase in circumference may be related to the reduction in thinness.

The limiting points of the current work involve the absence of biochemical data, mainly related to inflammation, and the absence of the exact hospitalization time until the application of the screening tool had been carried out. Such analyzes would provide tools to better determine the impact of the various infectious diseases analyzed on nutritional status and nutritional risk analysis. We believe that the consideration of these points is necessary for the realization of future related work, although the present study has made an important contribution. 


\section{Conclusion}

In summary, for patients with infectious diseases, acute malnutrition (BMI/age) is associated directly with the diagnosis of high nutritional risk by STRONGkids. The increase in arm circumference was a protective factor of high nutritional risk.

\section{References}

Beser, O. F., Cokugras, F. C., Erkan, T., Kutlu, T., Yagci, R. V., \& TUHAMAR Study Group (2018). Evaluation of malnutrition development risk in hospitalized children. Nutrition (Burbank, Los Angeles County, Calif.), 48, 40-47. https://doi.org/10.1016/j.nut.2017.10.020

Bhutta, Z. A., Berkley, J. A., Bandsma, R., Kerac, M., Trehan, I., \& Briend, A. (2017). Severe childhood malnutrition. Nature reviews. Disease primers, 3, 17067. https://doi.org/10.1038/nrdp.2017.67.

Brasil - Ministério da Saúde. (2011). Orientações para a coleta e análise de dados antropométricos em serviços de saúde: Norma Técnica do Sistema de Vigilância Alimentar e Nutricional - SISVAN. Ministério da Saúde, Secretaria de Atenção à Saúde, Departamento de Atenção Básica. Brasília: Ministério da Saúde, 76 p.

Carvalho, F. C., Lopes, C. R., Vilela, L.C., Vieira, M. A., Rinaldi, A. E. M., Crispim, C. A. (2013). Tradução e adaptação cultural da ferramenta Strongkids para triagem do risco de desnutrição em crianças hospitalizadas. Revista Paulista de Pediatria; 31(2): 159-65. https://doi.org/10.1590/S010305822013000200005

de Souza, H. P., de Oliveira, W., Dos Santos, J., Toledo, J. P., Ferreira, I., de Sousa Esashika, S., de Lima, T., \& de Sousa Delácio, A. (2020). Doenças infecciosas e parasitárias no Brasil de 2010 a 2017: aspectos para vigilância em saúde [Infectious and parasitic diseases in Brazil, 2010 to 2017: considerations for surveillanceEnfermedades infecciosas y parasitarias en Brasil de 2010 a 2017: aspectos para la vigilancia sanitaria]. Revista panamericana de salud publica = Pan American journal of public health, 44, e10. https://doi.org/10.26633/RPSP.2020.10

Erismann, S., Knoblauch, A. M., Diagbouga, S., Odermatt, P., Gerold, J., Shrestha, A., Tarnagda, G., Savadogo, B., Schindler, C., Utzinger, J., \& Cissé, G. (2017). Prevalence and risk factors of undernutrition among schoolchildren in the Plateau Central and Centre-Ouest regions of Burkina Faso. Infectious diseases of poverty, 6(1), 17. https://doi.org/10.1186/s40249-016-0230-x.

Feleke, B. E., Feleke, T. E., Biadglegne, F. (2019). Nutritional status of tuberculosis patients, a comparative cross-sectional study. BMC pulmonary medicine, 182(19); https://doi.org/10.1186/s12890-019-0953-0.

Gambra-Arzoz, M., Alonso-Cadenas, J. A., Jiménez-Legido, M., López-Giménez, M. R., Martín-Rivada, Á., de Los Ángeles Martínez-Ibeas, M., CañedoVillarroya, E., \& Pedrón-Giner, C. (2020). Nutrition Risk in Hospitalized Pediatric Patients: Higher Complication Rate and Higher Costs Related to Malnutrition. Nutrition in clinical practice: official publication of the American Society for Parenteral and Enteral Nutrition, 35(1), 157-163. https://doi.org/10.1002/ncp.10316.

Gashaw, F., Bekele, S., Mekonnen, Y., Medhin, G., Ameni, G., \& Erko, B. (2019). High helminthic co-infection in tuberculosis patients with undernutritional status in northeastern Ethiopia. Infectious diseases of poverty, 8(1), 88. https://doi.org/10.1186/s40249-019-0600-2

Gouveia, M. A. C., Tassitano, R. M., Silva, G. A. P. (2018). STRONGkids: Predictive Validation in Brazilian Children. Journal of Pediatric Gastroenterology and Nutrition. 67(3):51-6.

Harris, M., et al. (2012). Global report for research on infectious diseases of poverty. Organização Mundial da Saúde, 2012.

Hecht, C., Weber, M., Grote, V., Daskalou, E., Dell'Era, L., Flynn, D., Gerasimidis, K., Gottrand, F., Hartman, C., Hulst, J., Joosten, K., KaragiozoglouLampoudi, T., Koetse, H. A., Kolaček, S., Książyk, J., Niseteo, T., Olszewska, K., Pavesi, P., Piwowarczyk, A., Rousseaux, J., \& Koletzko, B. (2015). Disease associated malnutrition correlates with length of hospital stay in children. Clinical nutrition (Edinburgh, Scotland), 34(1), 53-59. https://doi.org/10.1016/j.clnu.2014.01.003.

Hussien, B., Hussen, M. M., Seid, A., \& Hussen, A. (2019). Nutritional deficiency and associated factors among new pulmonary tuberculosis patients of Bale Zone Hospitals, southeast Ethiopia. BMC research notes, 12(1), 751. https://doi.org/10.1186/s13104-019-4786-y

Huysentruyt, K., Goyens, P., Alliet, P., Bontems, P., Van Hautem, H., Philippet, P., Vandenplas, Y., \& De Schepper, J. (2015). More training and awareness are needed to improve the recognition of undernutrition in hospitalised children. Acta paediatrica (Oslo, Norway: 1992), 104(8), 801-807. https://doi.org/10.1111/apa.13014.

Maciel, J., Nakano, E. Y., Carvalho, K., \& Dutra, E. S. (2020). STRONGkids validation: tool accuracy. Jornal de pediatria, 96(3), 371-378. https://doi.org/10.1016/j.jped.2018.12.012.

Márquez Costa, M. V., \& Alberici Pastore, C. (2015). Herramienta de cribado nutricional versus valoración nutricional antropométrica de niños hospitalizados: ¿Cuál método se asocia mejor con la evolución clínica? [Nutritional screening tool versus anthropometric assessment in hospitalized children: which method is better associated to clinical outcomes?]. Archivos latinoamericanos de nutricion, 65(1), 12-20.

Moreno, J. P., Navazo, S. M., Arteta, E. L., Herbani, M. T., Martínez, F. G., Sánchez, M. I. G., Fernández, R. R. (2019). Influence of nutritional status on clinical outcomes in hospitalised children. Anales de Pediatría, 91(5): 328-335. https://doi.org/10.1016/j.anpede.2019.09.003.

Nalwang, D., Musiime, V., Kizito, S., Kiggundu, J. B., Batte, A., Musoke, P., Tumwine, J. K. (2020). Mortality among children under five years admitted for routine care of severe acute malnutrition: a prospective cohort study from Kampala, Uganda. BMC Pediatrics, 20(182): 1-11. https://doi.org/10.1186/s12887020-02094-w 
Research, Society and Development, v. 10, n. 11, e407101119859, 2021

(CC BY 4.0) | ISSN 2525-3409 | DOI: http://dx.doi.org/10.33448/rsd-v10i11.19859

Niseteo, T., Hojsak, I., \& Kolaček, S. (2020). Malnourished children acquire nosocomial infections more often and have significantly increased length of hospital stay. Clinical nutrition (Edinburgh, Scotland), 39(5), 1560-1563. https://doi.org/10.1016/j.clnu.2019.06.022.

Pereira, A. S. et al. (2018). Metodologia da pesquisa cientifica. UFSM. https://repositorio.ufsm.br/bitstream/handle/1/15824/Lic_Computacao_MetodologiaPesquisa-Cientifica.pdf?sequence $=1$.

Pooja, G., Shveta, L., Shivam, D., \& Abhishek, S. (2019). Malnutrition and Childhood Illness among 1-5-year-old Children in an Urban Slum in Faridabad: A Cross-Sectional Study. Journal of epidemiology and global health, 9(1), 19-22. https://doi.org/10.2991/jegh.k.190212.001

Put Bélanger, V., McCarthy, A., Marcil, V., Marchand, V., Boctor, D. L., Rashid, M., Noble, A., Avinashi, V., Davidson, B., Groleau, V., Spahis, S., \& Levy, E. (2019). Assessment of Malnutrition Risk in Canadian Pediatric Hospitals: A Multicenter Prospective Cohort Study. The Journal of pediatrics, 205, 160167.e6. https://doi.org/10.1016/j.jpeds.2018.09.045.

Rinninella, E., Ruggiero, A., Maurizi, P., Triarico, S., Cintoni, M., \& Mele, M. C. (2017). Clinical tools to assess nutritional risk and malnutrition in hospitalized children and adolescents. European review for medical and pharmacological sciences, 21(11), 2690-2701.

Sisay, B. G., Haile, D., Hassen, H. Y., \& Gebreyesus, S. H. (2021). Mid-upper arm circumference as a screening tool for identifying adolescents with thinness. Public health nutrition, 24(3), 457-466. https://doi.org/10.1017/S1368980020003869.

Teixeira, A. F., Viana, K. D. A. L. (2016). Nutritional screening in hospitalized pediatric patients: a systematic review. Jornal de Pediatria. 2016;92(4):343352. https://doi.org/10.1016/j.jped.2015.08.011

Waldman, E. A., \& Sato, A. P. (2016). Path of infectious diseases in Brazil in the last 50 years: an ongoing challenge. Revista de saude publica, 50, 68. https://doi.org/10.1590/S1518-8787.2016050000232

World Health Organization, Multicentre Growth Reference Study Group. (2006). WHO Child Growth Standards: length/height-for-age, weight-for-age, weight-for-length, weight-for-height and body mass index-for-age: methods and development. World Health Organization.

World Health Organization. Children: Reducing Mortality [Internet]. World Health Organization; https://www.who.int/news-room/fact-sheets/detail/childrenreducing-mortality. 